that of Spartina Townsendii, as its examination has been conducted for commercial rather than scientific ends. We are told, however, that this malvaceous plant is a hybrid biennial which comes true to seed and can be grown successfully in Devonshire, with vigorous production of fibre. The Brotex Company, of 10 New Burlington Street, London, has issued a booklet containing some very striking photographs of the plant under cultivation at Totnes, Devonshire. There seems little doubt also that a valuable fibre can be obtained from the plant; it has still, of course, to establish its place as a commercial source of fibre.

Again, we seem to be confronted with a case of vigorous cell wall production by a plant of hybrid origin. If the claims for the plant are justified and this vigour of growth maintained in subsequent years, as in the case of Spartina, once more the question arises whether linkage has established amongst the hybrid offspring a stable and vigorous race of plants.
Another alternative in such cases has to be borne in mind, and will doubtless form the subject of future investigation. In Citrus and in many other genera of plants, it is possible to maintain a hybrid race intact, although propagating by seed, because these seeds are actually asexually produced, so that though 'seed' is planted, the plants are actually members of one vegetatively propagated 'clone'.

The whole subject of the utilisation of hybrid vigour, for fibre production as for fruit and vegetable production in the service of man, is a fascinating topic fraught with great practical possibilities. In view, especially, of the utilisation of Britain's tropical resources, it is to be hoped that its investigation will not be left to America; but, on a conservative estimate, twenty times the number of scientific workers are engaged in the study of plant genetics in the United States compared with the number of workers in this field in the British Empire.

\title{
Obituary.
}

Mr. E. T. Newron, F.R.S.

$\mathrm{E}^{\mathrm{D}}$ DWIN TULLEY NEWTON, who died in London on Jan. 28, aged nearly ninety, was for many years a leader in the study of fossils in Great Britain. He was born in London in May 1840, and at an early age was apprenticed to a handicraft which gave him special skill in designing and carrying out delicate manipulations. He was at the same time deeply interested in natural history, and was fortunate in attracting the notice of Huxley, whose lectures he attended at the Royal School of Mines in Jermyn Street. Eventually, in 1865, he became assistant to Huxley, who was then naturalist to the Geological Survey, and henceforth he was able to follow his inclination and devote himself to the study of life, both recent and fossil. His official work, however, led to his dealing chiefly with fossils, and in 1882, when Mr. Robert Etheridge left for the British Museum, he was appointed palæontologist to the Geological Survey, a position which he occupied until his retirement under the agelimit in 1905.

Newton's earliest noteworthy success, arising out of his routine duties, was the preparation of the first satisfactory microseope-sections of coal, for use by Huxley in a lecture which he delivered at Leeds in 1870, and afterwards published in the Contemporary Review. These sections aroused much interest, because they revealed masses of spores as the chief constituent of certain bituminous coals, and Newton followed up the subject in his first scientific paper, which was published in the Geological Magazine in 1875. Next he turned to the difficult task of preparing a regular series of transverse sections through the brain of a cockroach, which he described, with the aid of his own drawings, in the Quarterly Journal of Microscopical Science in 1879. Each of these sections represented a known thickness, and Newton reproduced them exactly on an enlarged scale in a series of plates of soft pinewood. He then fixed the wooden plates together in regular order, and thus made a magnified model of the cockroach brain, which he described in the Journal of the Quekett Microscopical Club. This was one of the first attempts to make a model from serial sections, and it is now preserved in the Museum of the Royal College of Surgeons.

Newton's chief official duty as palæontologist to the Geological Survey, like that of his colleague George Sharman, was the preparation of lists of fossils for the memoirs which accompanied the maps. Throughout his career, however, he did much more than official routine, and found both time and opportunity to make many important contributions to our knowledge, especially of the fossil Vertebrata. His earliest researches of this kind were devoted to the Cretaceous fishes, and he published his results not only in short papers, but also in his well-known memoir on the "Cretaceous Chimæroid Fishes ", issued by the Geological Survey in 1878, and in the second edition of Dixon's "Geology and Fossils of Sussex", which appeared in the same year.

Most of the English Cretaceous fish-remains were fragmentary, and Newton was always fascinated by fragments, which needed special skill and patience for their interpretation. He was particularly interested in the scattered remains of the small mammals, birds, and fishes found in the later geological formations; and as the museums of London proved to be deficient in the skeletons of common existing animals which he wanted for comparison, he proceeded to make his own collection. He thus brought together a valuable series of exquisitely prepared skeletons, which included parts often neglected, such as the otoliths of fishes. Aided by this collection, he made great additions to our knowledge of the vertebrate fauna of Britain which immediately preceded the present, and his services were frequently sought when isolated bones and

No. 3147, VoL. 125] 
teeth were discovered in cave deposits and other comparatively recent geological formations. In this connexion may be specially mentioned his Survey memoirs on "The Vertebrata of the Forest Bed Series of Norfolk and Suffolk" (1882) and "The Vertebrata of the Pliocene Deposits of Britain " (1891), also his paper on the Pleistocene vertebrates from the Ightham fissure in Kent contributed to the Geological Society's Journal in 1894. He continued such researches at intervals until quite recently, his last paper, on a bone of a pelican from the Yorkshire peat, appearing in The Naturalist of June 1928. It may be added that Newton rarely dealt with controversial matters, but his account of a human skull found in a Pleistocene deposit at Galley Hill, Kent, published by the Geological Society in 1895, began a long discussion which still continues.

Of all Newton's contributions to vertebrate palæontology, however, the most fundamental were three memoirs on fossil reptiles published in the Philosophical Transactions of the Royal Society. In 1887, by the delicate preparation of the skull of a pterodactyl from the Upper Lias of Whitby, he gave the first satisfactory description of the brain of a flying reptile. In 1893 and 1894, by taking gutta-percha casts from the hollows left by the decay of bones which were once buried in the Permo-Triassic sandstones of Elgin, Scotland, he utilised in an astonishing manner a most unpromising collection of the remains of various land reptiles, and revealed several skulls and other parts of the skeleton of genera closely related to some previously found only in the Karroo formation of South Africa and in corresponding rocks in India.

Although occupied so much with research, Newton still found time to take an active part in the work of scientific societies in London. For several periods he was a member of council of the Geological and Palæontographical Societies and of the Geologists' Association. He was also a member of the publication and finance committees of the Zoological Society. He was president of the Geologists' Association in 1896-98, and president of the Palæontographical Society from 1921 to 1928 . He was elected a fellow of the Royal Society in 1893, and received the Lyell Medal from the Geological Society in the same year. To his scientific worth was added a charming personality, unassuming and kindly, which leaves happy memories with all who had the good fortune to be associated with him.

\section{A. S. W.}

\section{Sir George Dancer Thane.}

Sir George Thane died on Jan. 14 within four months of the eightieth anniversary of his birth. He was associated with University College, London, as student, demonstrator, professor of anatomy, and emeritus professor for more than sixty-three years. When only twenty years of age, and not yet qualified to practise medicine, he was chosen by Prof. George Viner EIlis for the office of demonstrator of anatomy, and seven years later, on Ellis's retirement,
Thane was appointed to succeed him in the professorship, which he occupied for forty-two years.

The mere enumeration of the forty-nine years which Thane devoted to the teaching of anatomy at University College represents only one aspect of the great services he rendered. Nor did the work or research in, and teaching of, anatomy form the major element in his whole-hearted devotion to University College and to anatomy. His greatest achievement was his cultivation of a personal knowledge of the students who worked under him, and of a sincere interest in their welfare, which he maintained throughout their subsequent careers. $\mathrm{He}$ became their lifelong friend. Thus his genial personality, and in particular his passion for accuracy in observation and restraint in expressing what he saw, influenced the lives of thousands of medical men and women. This played a large part in building up the solid reputation of medical education in London.

Thane had a very wide and exact knowledge of anatomical literature. Among his contemporaries he was personally acquainted not merely with their published works but also with the men themselves in their laboratories and their social life. By his own investigations he acquired the critical instrument for assessing the value of other anatomists' work, and his judgment and power of lucid expression made his own writings a sober and wonderfully accurate picture of the state of anatomical knowledge.

Like his predecessors in the chair of anatomy at University College-the men who created " Quain's Anatomy" and made it the standard text-book which was adopted as a model throughout the world -he put his best work into this book, rather than into the scientific journals. His contributions to the 9th and 10th editions of "Quain's Anatomy" not merely maintained the high qualities and reputation of the work, but also extended its range and precision, and made it the most reliable and adequate text-book on the subject that at the time had been produced.

Thane was one of the founders of the Anatomical Society of Great Britain and Ireland, and years afterward when he became its president the respect in which he was held abroad was shown by an exceptionally large attendance of distinguished foreign anatomists. Thane was an active member of the German and French anatomical societies, and took a delight in attending their meetings, as well as the international anatomical congresses.

During his years of service as inspector of experiments on living animals, Thane took a keen interest in acquiring a personal knowledge of physiologists and in facilitating their work. He was an honorary D.Sc. of Dublin and LL.D. of Edinburgh, and on his retirement from the active work of his professorship a knighthood was conferred upon him in recognition of his public service. $\mathrm{By}$ his death his former students have lost a wise and kindly friend and the science of anatomy a teacher who unobtrusively did a vast amount of work to establish the foundations of an exact knowledge of the human body.

No. 3147, VoL. 125] 